\title{
Unusual Magnetic Resonance Imaging Appearance of Multiple Cystic Lesions in Glioblastoma Multiforme
}

\author{
Glioblastoma Multiforme'de Çok Saynda Kistik Lezyon Şeklinde \\ Olağandışı Manyetik Rezonans Görüntüleme Görünümü
}

\author{
Mark LYONS \\ Mayo Clinic Arizona, Department of Neurological Surgery, Phoenix/AZ, USA
}

Correspondence address: Mark LYONS / E-mail: lyons.mark2@mayo.edu

\begin{abstract}
The differential diagnosis of multiple ring-enhancing intraaxial lesions includes neoplastic, infectious, inflammatory, demyelinating and vascular lesions. We report a case of a 41-year-old man who presented with a brief history of left lower extremity weakness and sensory loss. Magnetic resonance imaging demonstrated multiple ring-enhancing lesions in the right frontal and parietal lobes. Neuroradiology interpretation was felt to be unlikely for a neoplastic process. The patient underwent stereotactic brain biopsy, which was diagnostic for glioblastoma multiforme. This case demonstrates the importance of histological confirmation of intraaxial brain lesions whenever feasible. The course of his disease and treatment are discussed and the literature reviewed.
\end{abstract}

KEYWORDS: Glioblastoma multiforme, Ring-enhancing, Brain biopsy, Magnetic resonance imaging

öz

Çok sayıda halka şeklinde kontrast tutan intraaksiyal lezyonların ayırıı tanısı arasında neoplastik, enfeksiyöz, enflamatuvar, demiyelinizan ve vasküler lezyonlar vardır. Kısa bir sol alt ekstremite zayıflı̆ı ve duyu kaybı öyküsüyle başvuran 41 yaşında bir erkeği sunuyoruz. Manyetik rezonans görüntüleme sağ frontal ve parietal loblarda çok sayıda halka şeklinde kontrast tutan lezyon gösterdi. Nöroradyolojinin yorumu neoplastik bir süreç olmasının pek olası olmadığı şeklindeydi. Hastaya stereotaktik beyin biyopsisi yapıldı ve glioblastoma multiforme tanısı kondu. Bu vaka mümkün olduğunda intraaksiyal beyin lezyonlarının histolojik olarak doğrulanmasının önemini göstermektedir. Hastalığın seyri ve tedavi anlatılmakta ve literatür gözden geçirilmektedir.

ANAHTAR SÖZCÜKLER: Glioblastoma multiforme, Halka şeklinde kontrast tutan, Beyin biyopsisi, Manyetik rezonans görüntüleme

\section{INTRODUCTION}

Glioblastoma multiforme (GBM) remains one of the most aggressive and lethal forms of tumors of the brain. The magnetic resonance (MR) imaging features can, in some cases, be nearly pathognomonic. However, there are radiographic findings that can suggest a process other than a primary neoplasm of the brain. Inflammatory, infectious, demyelinating, ischemic and metastatic disease can be considered in the differential based upon the MR images. We present the case of a man with a rapidly developing hemiparesis. The MR study revealed an unusual pattern of multiple cystic masses. We discuss his evaluation, treatment and the literature regarding cystic masses in GBM.

\section{CASE REPORT}

A 41-year-old left-handed male was transferred to our institution with a three-week history of left lower extremity weakness and numbness. He had intermittent headaches and no other systemic complaints. He was noted to be afebrile with normal laboratory studies. A magnetic resonance (MR) imaging study of the brain revealed dozens of ring-enhancing lesions in the posterior frontal and anterior parietal lobes on the right with extension into the posterior centrum semiovale. Diffusion imaging was abnormal. There was mass effect and adjacent vasogenic edema (Figures 1-3). The appearance was felt by neuroradiology to be very unusual for a neoplastic process. Infection, such as fungal, tuberculosis or cysticercosis, was felt to be the most likely diagnosis. Metastatic workup, including computerized tomography (CT) of the chest, abdomen and pelvis were negative. The patient underwent a stereotactic brain biopsy of one of the lesions. Pathology was diagnostic for glioblastoma multiforme. Postoperatively, the patient remained in stable neurologic condition. He underwent fractionated external beam radiation treatment of 5600 cGy and temozolamide. Six months after completion of his radiation therapy, he developed progressive disease and expired ten months following diagnosis.

\section{DISCUSSION}

Glioblastoma multiforme (GBM) is the most common and aggressive primary malignant brain tumor in adults $(1,3,6,8)$. The MR appearance of GBM is often an irregular 


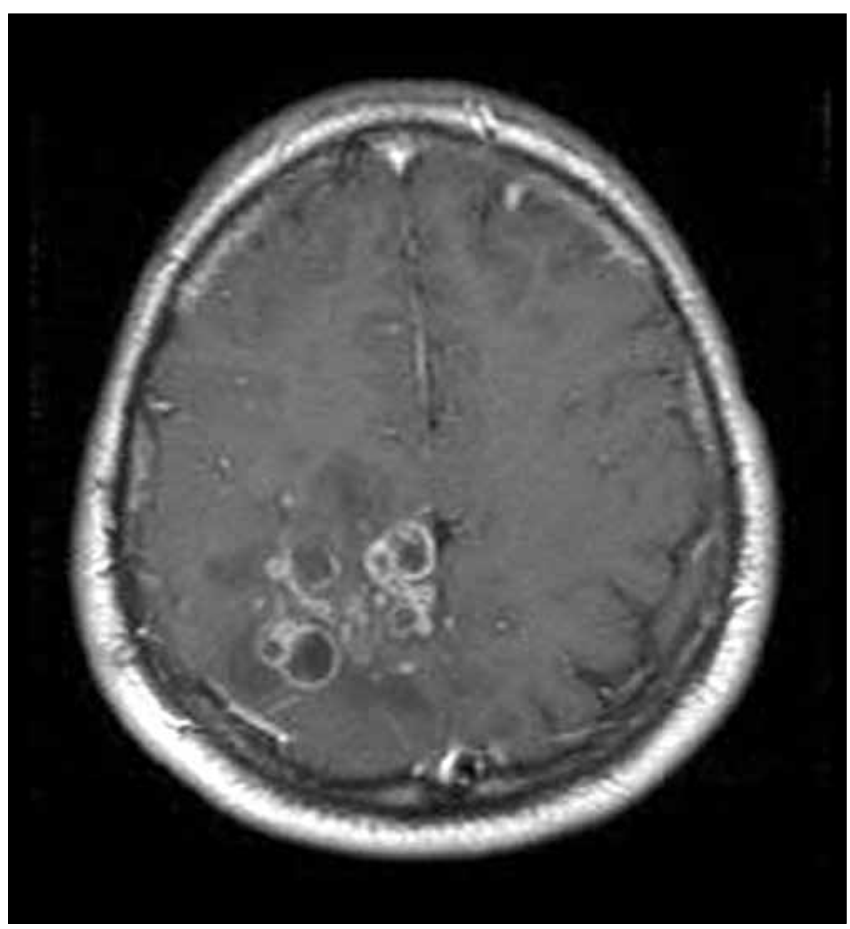

Figure 1: T-1 weighted axial brain MR demonstrating multiple ring-enhancing lesions in the posterior frontal lobe and anterior parietal lobe.

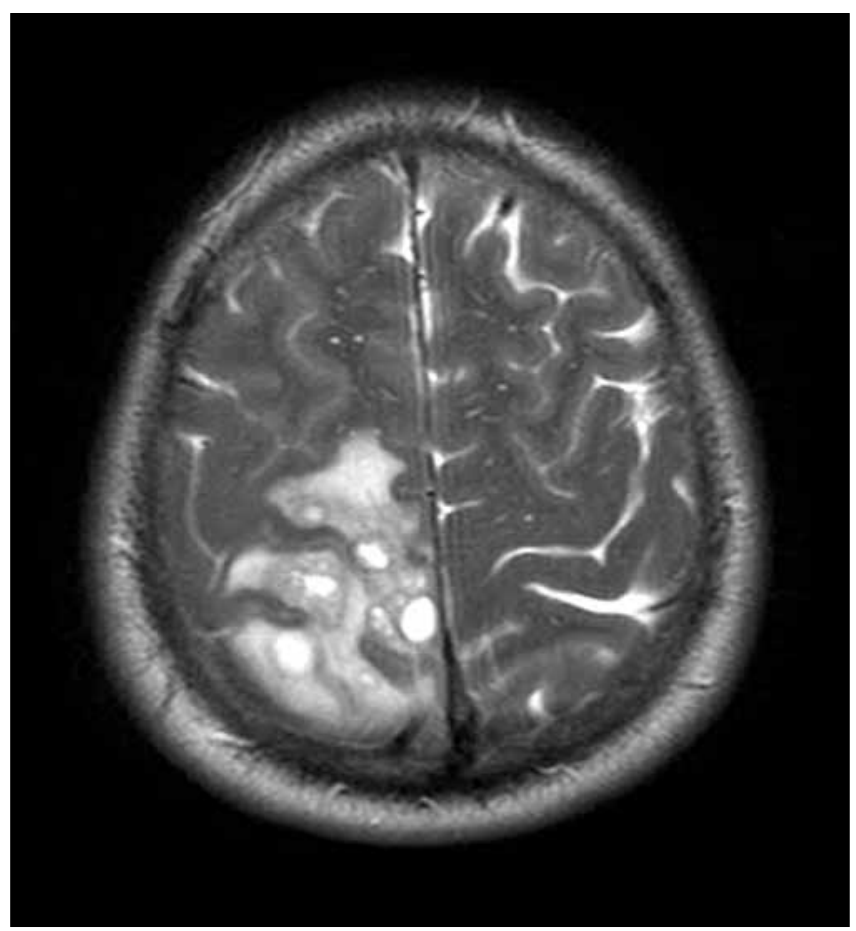

Figure 2: T-2 weighted axial brain MR demonstrating multiple ring-enhancing lesions in the posterior frontal lobe and anterior parietal lobe vasogenic edema and mass effect.

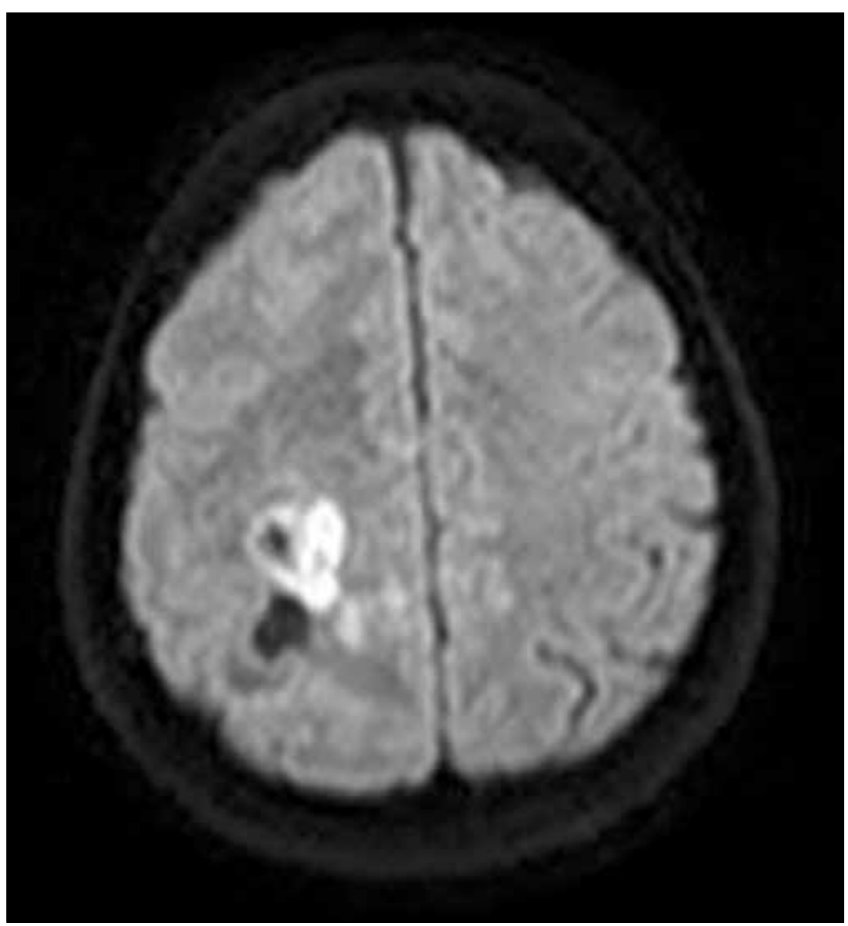

Figure 3: Diffusion axial brain MR revealing abnormal signal potentially consistent with infarct or infectious etiology.

heterogeneouslyenhancing mass with significant surrounding vasogenic edema $(2,4,9)$. Cystic components of GBM are reported but the presence of multiple smaller cystic lesions is uncommon $(3,6)$. Other tumors, such as meningiomas often will have cystic components identified radiographically and can be difficult to distinguish from intraaxial tumors. A recent study by Hakyemez et al. reported their findings that regional cerebral blood flow ( $\mathrm{rCBV}$ ) ratios with construction of signal intensity-time curves can be useful in discerning malignant tumors, such as GBM, from meningioma (3). An interesting case by Muragaki and colleagues reported the simultaneous presence of three distinct intraaxial masses (7). One of the masses demonstrated several small cystic cavities on MR and confirmed by pathology to be a central neurocytoma. The other two masses were resected and found to be glioblastoma multiforme but did not exhibit cystic features on preoperative magnetic resonance imaging.

The diffusion of contrast media secondary to the disruption of the blood brain barrier has been shown to correlate well with histological findings of neovascularity and endothelial proliferation (2). Both of these features are found in glioblastomas (9). The most common MR findings of GBM are a heterogeneous mass in the white matter with vasogenic edema, thick irregularly enhancing walls and necrosis. While cystic appearance with associated thin round walls has been reported in GBM, this finding is unusual (9). Occasionally, the cystic mass will harbor a mural nodule of enhancement. However, it is rare to see multiple cysts. Masdeu and coworkers reported the open-ring imaging sign as highly specific for atypical brain demyelination (5). They found in 
their meta-analysis that demyelinating lesions more often had an "open-ring" or incomplete ring of enhancement surrounding the low intensity area of the mass, whereas, neoplastic and infectious lesions more often had a closed ring of enhancement (5). However, while these MR findings could aid in differentiating between demyelinating lesions versus infectious or neoplastic; they were not absolute. While noted in some cases of metastatic disease, there are no reports of multiple small cystic lesions as the presenting MR imaging findings in glioblastoma multiforme. Several reports have noted. that the typical MR findings of GBM can be absent $(2,4-6,9,10)$. Histological confirmation is essential in order to establish the diagnosis, direct appropriate treatment and predict prognosis.

\section{CONCLUSIONS}

The MR imaging features of GBM are varied. We present the findings of histologically confirmed GBM with very unusual MR appearance. Multiple thin ring-enhancing lesions in the right posterior frontal and anterior parietal lobes with increased diffusion abnormality in GBM are rare. These lesions can easily be mistaken for an infectious etiology including tuberculosis, fungus and cysticercosis. Stereotactic brain biopsy remains critical to establish the correct diagnosis.

\section{REFERENCES}

1. Burger PC, Pearl DK, Aldape K, Yates AJ, Scheithauer BW, Passe SM, Jenkins RB, James CD: Small cell architecture - a histological equivalent of EGFR amplification in glioblastoma multiforme? J Neuropathol Exp Neurol 60:1099-1104, 2001

2. Earnest F, Kelly PJ, Scheithauer BW, Kall BS, Cascino TL, Ehman RL, Forbes GC, Axley PL: Cerebral astrocytomas: Histopathologic correlation of $\mathrm{MR}$ and $\mathrm{CT}$ contrast enhancement with stereotactic biopsy. Radiology 166: 823-827, 1988
3. Hakyemez B, Yildirim N, Erdogan C, Kocaeli H, Korfali E, Parlak $M$ : Meningiomas with conventional MRI findings resembling intraaxial tumors: Can perfusion-weighted MRI be helpful in differentiation? Neuroradiology 48:695-702, 2006

4. Iwama T, Yamada H, Sakai N, Andoh T, Nakashima T, Hirata T, Funakoshi T: Correlation between magnetic resonance imaging and histopathology of intracranial glioma. Neurological Res 13(1):48-54, 1991

5. Masdeu JC, Quinto C, Olivera C, Tenner M, Leslie D, Visintainer $\mathrm{P}$ : Open-ring imaging sign highly specific for atypical brain demyelination. Neurology 54:1427-1433, 2000

6. Mihara F, Numaguchi Y, Rothman M, Sato S, Fiandaca MS: MR imaging of adult supratentorial astrocytomas: An attempt of semi-automatic grading. Radiation Med 13(1):5-9, 1995

7. Muragaki Y, Chernov M, Tajika Y, Kubo O, Iseki H, Hori T, Takakura K: Coincidence of central neurocytoma and multiple glioblastomas: A rare case report. J Neurooncol 93:431-435, 2009

8. Pina-Oviedo S, De Leon-Bojorge B, Cuesta-Mejias T, White MK, Ortiz-Hidalgo C, Khalili K, Del Valle L: Glioblastoma multiforme with small cell neuronal-like component: Association with human neurotropic JC virus. Acta Neuropathol 111:388-396, 2006

9. Rees JH, Smirniotopoulos JG, Jones RV, Wong K: Glioblastoma multiforme: Radiologic-pathologic correlation. Radiographics 16(6):1413-1438, 1996

10. Rogers LR, Weinstein MA, Estes ML, Cairncross JG, Strachan T: Diffuse bilateral cerebral astrocytomas with atypical neuroimaging studies. J Neurosurg 81(6):817-821, 1994 